\title{
Shifting sedentism in the Upper Gasamance (Senegal)
}

\author{
Sirio Canós Donnay
}

Institute of Archaeology, University College London, 31-34 Gordon Square, London, WCIH OPY, United Kingdom

\begin{abstract}
The Upper Casamance is a region that has witnessed dramatic socio- political developments in the last millennium, including its conquest by the Mali Empire and a prominent role in the Atlantic trade, but which until now had never been archaeologically studied. Two seasons of fieldwork undertaken in 2013 revealed a landscape of shallow, short-lived sites at odds with the large permanent towns described by historical accounts and oral traditions. This article argues that the key to reconciling these two sets of evidence lies in a very particular settlement pattern - one of 'shifting sedentism' - by which villages and towns regularly shifted a few hundred metres, while keeping the name, identity, and institutions of the community intact. Combining data from ethnographic observations, written historical sources, oral traditions, surface survey and excavation, the paper reviews the importance of shifting sedentism in the Upper Casamance's history, as well as its wider archaeological implications.
\end{abstract}

\section{Introduction}

The Upper Casamance or Kolda region, is the westernmost part of the Casamance, the strip of land in the south of Senegal that separates The Gambia from Guinea-Bissau (Figure 1). It is a largely flat area, with sandy and clayey sandstones forming plateaux and occasional lateritic outcrops. Vegetation is abundant, combining savanna and light forest, crisscrossed by a multiplicity of seasonal and permanent watercourses that make it one of Senegal's most fertile regions. The large majority of the current population $(75 \%)$ self-identifies as Fulbe, but there is also a substantial presence of Manding (7.31\%) and Wolof (7.22\%), as well up to twenty other groups in smaller numbers (ANSD 2009: 9-10). Nowadays one of Senegal's most underdeveloped regions, the Upper Casamance has, over the last millennium, been at the core of some of West Africa's key trading networks and political processes, including the rise and fall of states and empires. Yet, until now, its archaeology has never been systematically studied.

Prior to this project, we had three sources on the Upper Casamance's past: oral traditions, accounts from European travellers from the fifteenth century onwards and the observations of the anthropologist Jean Girard (1992), including some of archaeological nature regarding the subterranean structures locally known as guide. Together, these sources drew a sketch of the region's history, according to which the first inhabitants would have been the Bainouk, whose descendants still live in the Lower Casamance. In the thirteenth century, the Bainouk would have been either expelled or assimilated by the arrival of Manding warriors, who annexed the region to 
the Mali Empire, calling it Kaabu. While the exact nature and chronology of this annexation are not clear, we know that by the time of the arrival of the Portuguese on the West African coast, Kaabu already controlled a large part of the Senegambian region. Kaabu's power and autonomy grew over the following centuries, eventually gaining independence from Mali after the disintegration of the latter in the late sixteenth to seventeenth centuries. It was only in the late nineteenth century when a combination of internal and external problems, most notably a Fulbe revolt, put an end to Kaabu's rule, giving way to the short-lived Fulbe state of Fulaadu before the onset of the colonial period

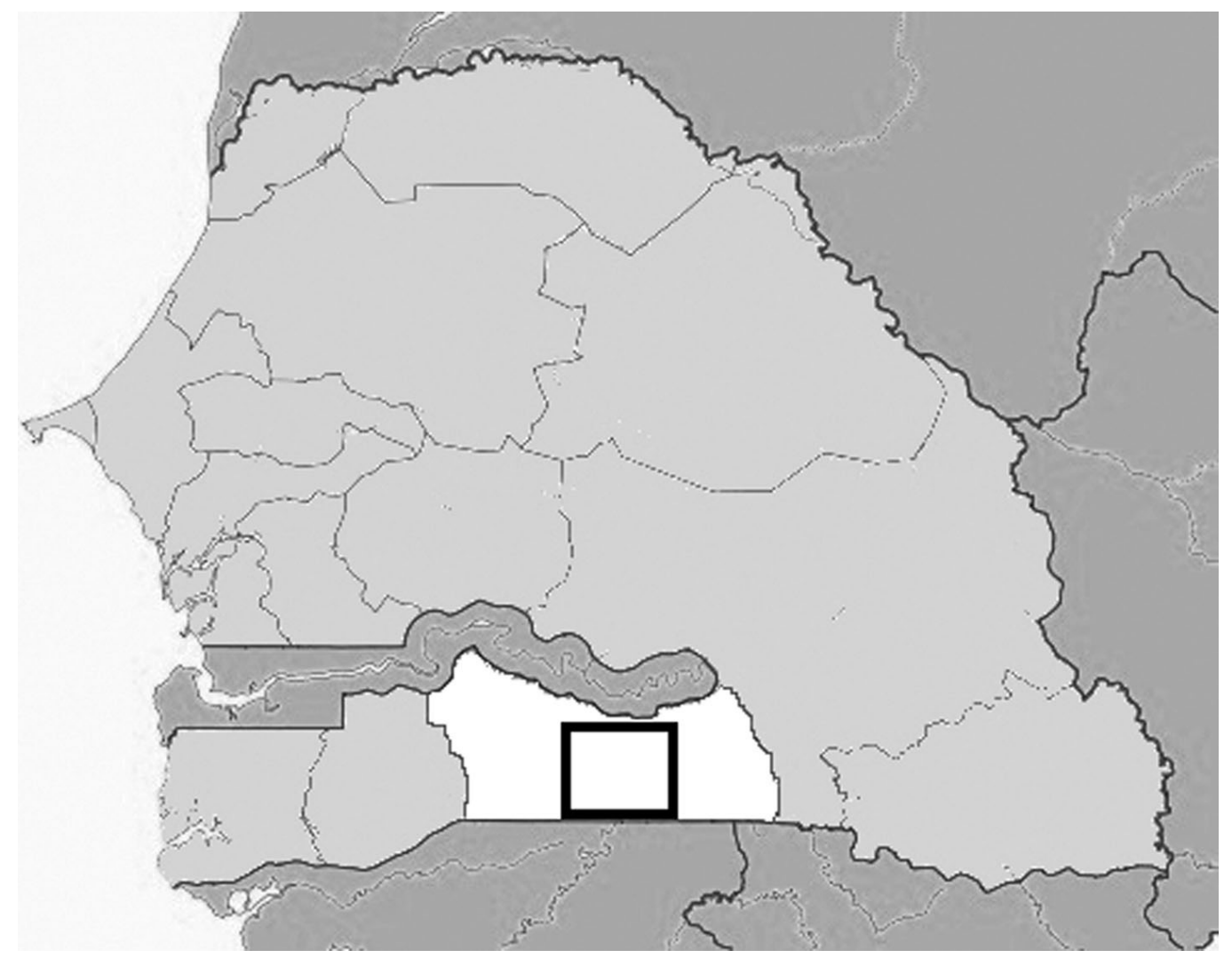

Figure 1. Map of Senegal showing the Upper Casamance region in white and this project's research area in black.

With this background information, work began in 2013 to document the archaeology of the Upper Casamance through a combination of surface survey, excavation and collection of oral traditions. In the absence of any prior archaeological information beyond Girard's occasional remarks, I decided to begin fieldwork in the triangle formed by the three historical towns of Mampatim, Kabendou and Payoungou, which featured prominently in both oral traditions and written accounts as key power centres of Kaabu. As our historical knowledge of the area grew, this area was expanded to cover a $70 \times 50 \mathrm{~km}$ rectangle (Figure 1) including other secondary power centres 
(Kandia, Korop, Koumambouré, Patim Tibo), as well as a range of different geomorphological areas, like the Velingara crater and the forested regions near the Guinea-Bissau and Gambian borders. Given the antiquity attributed to all of these centres by oral traditions, the descriptions of Kaabu's great fortified towns in Portuguese and French accounts (e.g. Alvares de Almada 1964 [1594]: 45; Hecquard 1853: 204) and the region's strong affiliation with the Mali Empire, I initially expected to find an archaeological landscape similar to that in central Mali, with its tell-sites and long stratigraphic sequences. Instead, I encountered a landscape of consistently shallow and shortlived sites, apparently at odds with the large permanent sites described by the other sources.

I argue in this article that the key to reconciling these two sets of evidence lies in a very particular settlement pattern, which I have called 'shifting sedentism', by which villages and towns regularly shifted a few hundred metres, while keeping the name, identity and institutions of the community intact. This is a pattern that is still characteristic of the region today and that both historical written documents and oral traditions suggest was also operative historically. I draw from oral histories, ethnographic observations and archival material to review the nature and evolution of shifting sedentism and mobility patterns more widely throughout the region's history and explore the extent to which the archaeological evidence uncovered during my own fieldwork matches those patterns. I conclude with a brief reflection on the implications of shifting sedentism for our understanding of the history of the Upper Casamance, as well as for archaeological methodologies and the relation between statehood and mobility more widely.

\section{Shifting settlements in the archaeological literature}

Debates about mobility have a long history in archaeology (e.g. Murdock 1967; Higgs and VitaFinzi 1972; Rafferty 1985; Binford 1990: 122). Traditionally, however, these debates have been based on a sharp conceptual divide between mobile and sedentary populations and have focused on the generation of classificatory schemes conceived as socio-evolutionary stages and/or entailing assumptions about the subsistence, political institutions or social organisation of the group in question (Kelly 1992; Lindsay and Greene 2013).

Although more recent studies have started to rectify these deficiencies and to expand mobility studies beyond their traditional focus (e.g. Barnard and Wendrich 2008), the particular type of mobility discussed here (sedentary settlements that regularly 'shift') has not yet entered theoretical debates. It has, however, been documented in both archaeological and ethnographic contexts, mostly in terms of village movements related to shifting agri- culture practices, such as those of present-day Yanomamo horticulturalists in southern Venezuela (Craig and Chagnon 2006), the fifteenth- to seventeenth-century Haudenosaunee in the northeastern United States of America (Jones and Wood 2012) and the eighth- to tenth-century Anasazi of southwestern Colorado (Kohler 
and Matthew 1988). These studies tend, however, to see residential mobility as stemming mostly - or even exclusively - from soil degradation associated with extensive agriculture and thus often fall into environmentally deterministic arguments.

Beyond the Americas, instances of shifting villages have also been reported for Medieval Central Europe, where 'accounts tell of dwellings being moved to where the next job was or onto a patch of vacant land. Whole villages moved when the soil was exhausted or when they were threatened by enemy attack' (Jackson 1984: 94). This notion of sedentary mobility is also picked up by Braudel (1981: 271), who describes how in rural areas of medieval France and Germany 'often, the centre of gravity within a given cultivated area shifted, and everything - furniture, people, animals, stones - was moved out of the abandoned village to a site a few kilometres away'. Closer to the Upper Casamance, in the central part of The Gambia, Amy Lawson provides a description of the same phenomenon, noting how:

'according to elders in the Gambia, it is quite common for villages of up to 1000 individuals to relocate (usually less than $1 \mathrm{~km}$ away) if the village chief or lineage head dies, or if agricultural fields become exhausted. However, during the c. 50-100 years in which a particular locale is inhabited, substantial houses are erected and individuals are "sedentary". This results in a settlement pattern in which a particular village sequentially locates itself in a number of discrete locales all within a relatively small area, a strategy which I am calling "serial sedentism". Even though the sites themselves appear ephemeral, this does not mean that the communities that produce them are' (Lawson 2003: 18).

Unfortunately, this insightful account - which coincides entirely with my own observations in the Upper Casamance - is the only mention of this phenomenon in Lawson's work. Consequently, although not unknown, the existence of patterns of shifting sedentism is heavily under-theorised. The vast majority of archaeological texts on mobility are concerned almost exclusively with nomadism, while existing analysis of shifting villages rarely go beyond simple environmental determinism or explore the relation of these shifts to political structures and their implications. It is likely, however, that the absence of a unifying term to group these phenomena has led to an under-representation in the literature of what could be a much more widespread phenomenon and that a richer comparative literature will emerge in the coming decades.

Settlement mobility in the Upper Casamance's present and recent past

Even though the vast majority of the Upper Casamance's population is now sedentary — including the notionally nomadic pastoralist Fulbe - mobility is still an inescapable feature of life in the region. Individuals move frequently due to seasonal or permanent work opportunities, studies, marriages or personal disagreements and movements of groups or even entire villages are also common. As the geographer Sylvie Fanchette (2010: 80) noted: 
'encore fortement empreints de croyances préislamiques, les Peuls Fulakunda fuient presque systématiquement les villages frappés par la mort. Qu'un chef de village ou un marabout puissant décède, que plusieurs personnes viennent à mourir dans la même concession, ou qu'une partie du troupeau soit décimée par maladie, et les Peuls abandonnent leur village pour s'installer ailleurs [...] Parfois, on ne quitte que sa concession pour la reconstruire dans une autre partie du village.'

Mobility is not, however, limited to the Fulbe. For instance, Pellissier (1966) documented how in the 1950s Balant villages in the Middle Casamance shifted a few hundred metres once a year to preserve soil fertility, while the interviews undertaken for this project (UC 2013) showed how different degrees of mobility have been a key feature of villages across the region, regardless of their ethnic composition, for at least a century. These village movements are of two types: shifts $(<1 \mathrm{~km})$ and relocations $(>1 \mathrm{~km})$. Relocations can, in turn, be divided into four main categories: 1) a segment of a village moves to another existing village; 2) a segment moves out and creates its own village; 3) a complete village abandonment takes place, followed by a new village foundation elsewhere; and 4) a complete village abandonment is followed by population dispersal into several existing villages. The reasons triggering people to leave are quite varied, as are those that lead people to settle in a new place. Abandonment motifs include disagreements with other groups within the village, the desire to create their own place, the death of a community leader and a series of deaths within a short time. In some cases, villages were abandoned as a result of the insecurity created by political instability in neighbouring Guinea-Bissau during its independence struggle between 1963 and 1974, but in all the instances I have documented these abandonments were only temporary and the populations eventually returned. The reasons for choosing an existing village as new residence had to do with family or friendship connections with the village head, or with an economic agreement with the village's head.

The second type of movement — 'shifts' — is less obvious and is rarely mentioned by oral traditions unless explicitly asked, although it is by no means less common. Except for very recent foundations, most of the villages visited had 'moved' from their original position. Sometimes these moves were punctuated and each of the individual moves was remembered. In other instances, however, the movement appeared to have been more gradual and no individual moves were remembered, only the evidence of their accumulated displacement reflected in the distance between the original and the present location of the village. The reasons given for these 'shifts' were also quite varied: in villages along the central axis of the region, the most common reason was the construction of the tarmac road and the benefits derived from its proximity, but earlier shifts reflected more diverse factors, following similar reasons to those for village abandonments (UC 2013).

A particularly illustrative example of the operation of this pattern is the village of Samasansan (Figure 2). This village was initially founded in the 1860s following the battle of Kansala (Kaabu's final defeat) by a group of Manding warriors who settled south of the valley. However, the area 
turned out to be too humid, so after a year the village moved to the other side of the valley. This second settlement was also abandoned some years later following a series of deaths and the population moved to found Touba (now

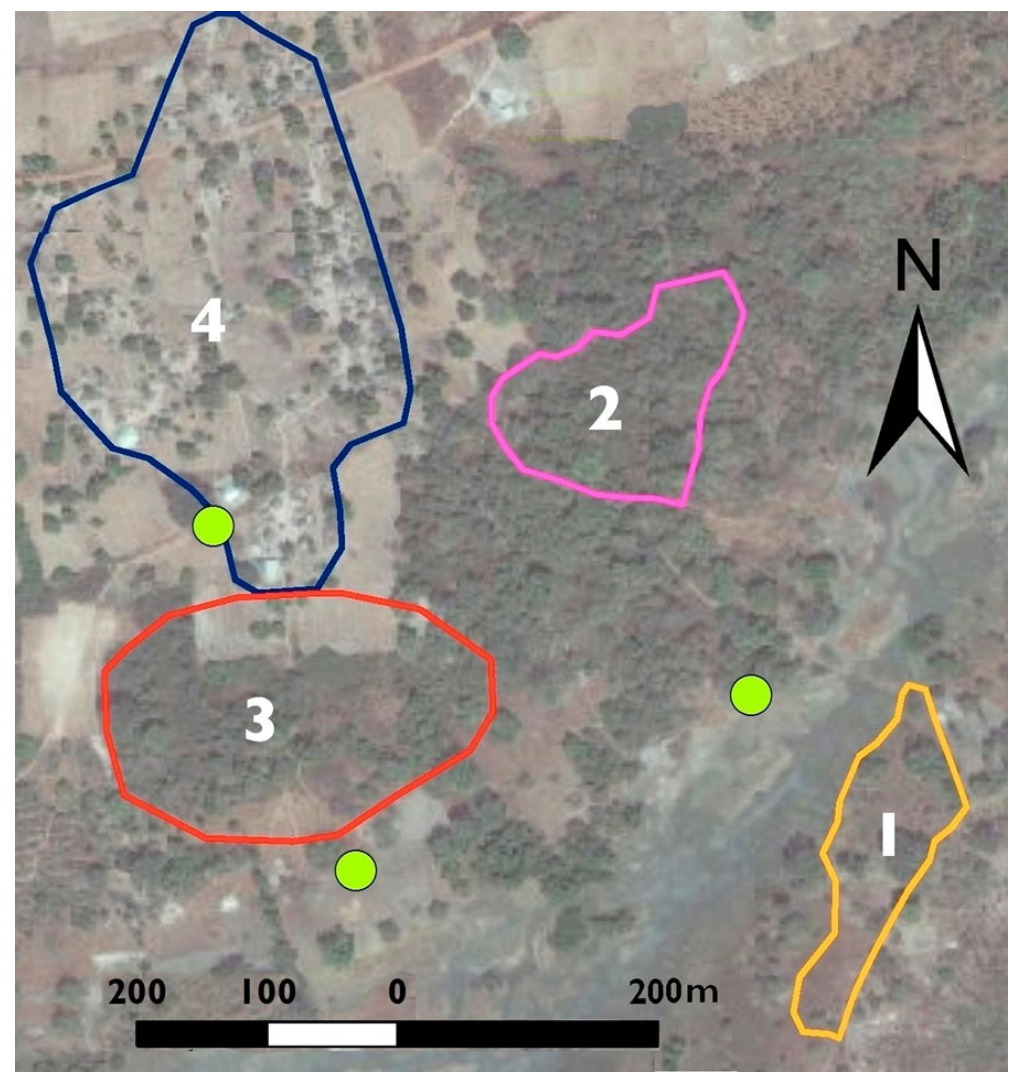

Figure 2. The village of Samasansan (Kolda region) with its four consecutive locations in the last 150 years. Basemap: (C2016 Google, C2016 Digital Globe. 


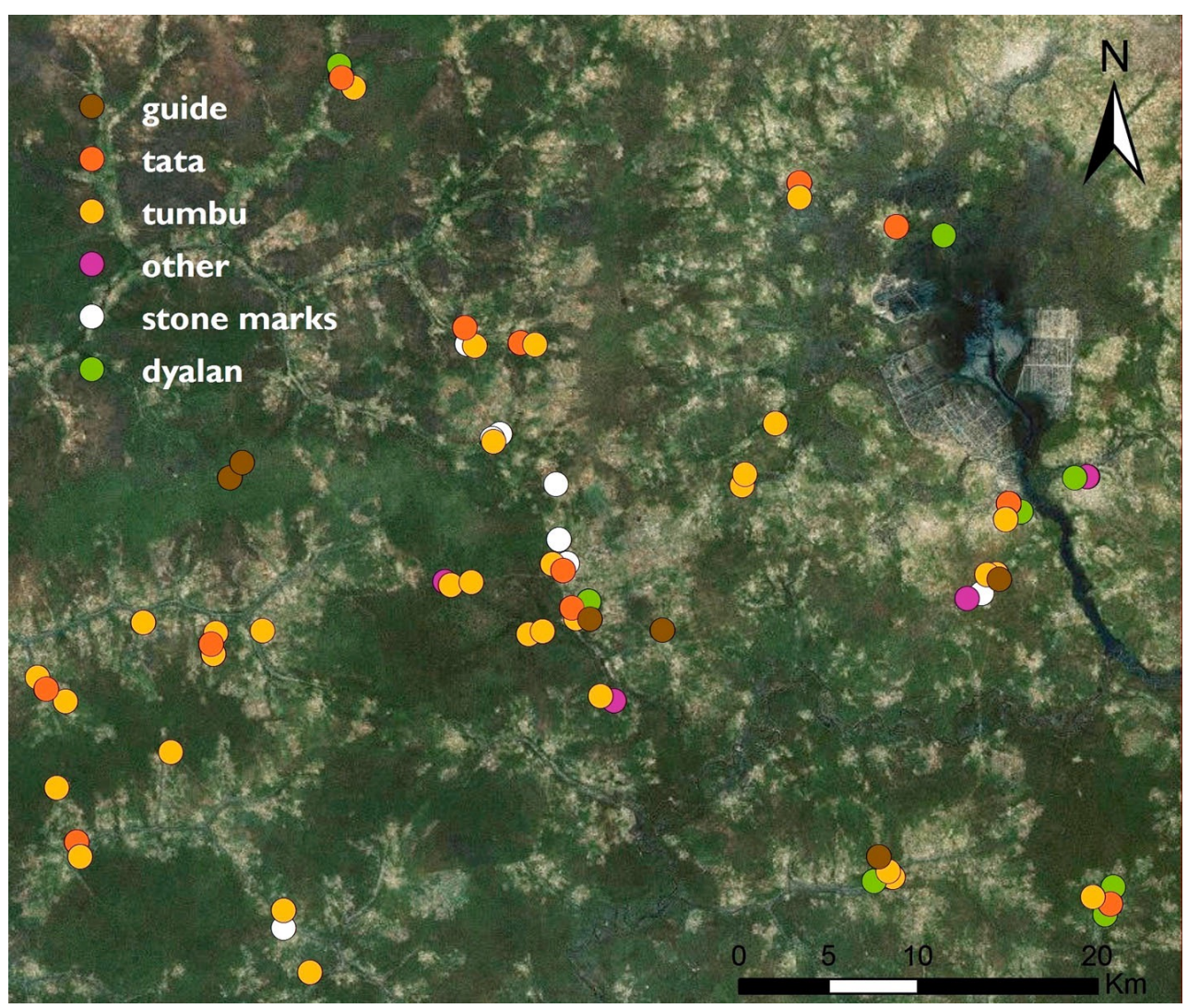

Figure 3. Upper Casamance: the research area and sites identified during the survey, including guide (caves and subterranean structures), tata (fortifications), tumbu (abandoned settlements), stone marks and dyalan (shrines). Basemap: (C2016 Google, (C2016 Digital Globe.

Medina Poussang), $3 \mathrm{~km}$ away. In the 1900s, a Fulbe by the name of Molo Saba decided to refound Samasansan and was told by the marabouts that the village could never succeed without Manding presence. He thus went to Medina Poussang to ask its inhabitants to return and together they created a new village to the southwest of the previous one. The village stayed there until the 1960s, when it moved to its current location (UC 2013, Interview 30).

\section{Settlement mobility in the Upper Casamance historically}

In addition to current or recent observations, we also have indications that constant movements and shifts have been a trait of the Upper Casamance's settlement patterns historically. During the colonial period, there were significant displacements associated with forced labour and military service, as well as repopulations to ensure the viability of cash crop cultivation (Pellissier 1966; Roche 1985; Fanchette 2010; Boutillier 2011). In addition to movements directly or indirectly connected to colonialism, patterns of short and long distance mobility similar to those currently existing appear to have already been in place. For example, in 1904, the Upper Casamance's 
colonial administrator Charles de la Roncière mentioned how new village foundations were extremely common, as it was believed that the more settlements a man had founded, the happier he would be in the afterlife (Fanchette 1999: 176). As this is a period that still falls within living memory, a large number of the oral histories collected during our own inter- views also testify to regular relocations and shifts of village segments and whole communities (UC 2013).

Although the number and quality of the sources decrease as we go further back in time, similar patterns appear to have been in operation at the end of Kaabu and during Fulaadu, albeit for different reasons. These were turbulent times, involving substantial abandonments and displacements due to the insecurity generated by the breakdown of Kaabu's political structures. Migrations out of small villages towards larger safer towns and to more stable areas in GuineaBissau and The Gambia appear to have been frequent (Fanchette 2010: 32). Additionally, according to local traditions it was common to encounter travelling groups of Manding blacksmiths that settled wherever a local ruler offered them protection in exchange for their services (UC 2013, Interviews 17 and 21). Despite the insecurity, village traditions reveal that a substantial number of villages were founded or re-founded in this period, including Pidiro, Samasansan, Diankancounda and Mampatim Sinthian (UC 2013, Interviews 11, 21, 28 and 30). This instability in settlement was captured by the French explorer Bertrand-Bocandé (1849: 58), who reported how the Fulbe people:

'reste sur les terres qu'on lui a prêtées tant qu'il y trouve une hospitalité convenable; il se tient toujours prêt à partir. S'il redoute quleques exactions, il déserte dans un instant et va s'établir ailleurs avec ses troupeaux, emportant toute ce qui lui appartient; il n'abandonne que ses ché- tives cases de paille.'

Another important factor shaping settlement dynamics over the region's history is slavery. Although the nature and intensity of slave raiding changed substantially over time, its influence over settlement patterns appears to have been a constant factor. As Kekouta Camara, an elder from Kabendou, explained: 'if they made war, all the children ${ }^{1}$ captured were taken home' (UC 2013, Interview 12). At present we have no way of quantifying the extent of the population movements caused by slavery in its early forms, but we do know that in later periods, when slaves became goods that could be sold in European trading entrepôts, the scale of the phenomenon was substantial. For instance, in the early eighteenth century the Kaabu king sold 600 slaves annually to the Portuguese alone, but also kept a substantial amount of them at court (Labat 1728: 234). In the nineteenth century, war captives were often taken back to the capital as free labour or redeployed as military garrisons to protect the polity's borders. Later on, as the abolition of slavery became gradually effective, the newly emancipated slaves moved again, leading to a substantial wave of new village creations (Fanchette 1999: 170).

As for short-distance mobility, or shifts, there is no direct mention or description in written sources, 
but it is necessary to bear in mind that, being a more gradual and subtle process, it could have easily gone unnoticed for occasional external observers. Oral traditions, on the other hand, do include reference to shifts, like this description of his ancestors' behaviour by Payoungou Seydi, an elder from the historical town of Payoungou:

'if they settled in a place where there were many deaths, they would move, with a jump of a few metres. And they would never go back. The tata (fortification) that I know of, never moved. It was the people who moved towards and around the tata. Thus the tata I know in Payoungou stayed in the same place. It was the village that moved around it. This movement was constant. The elders told me so' (UG 2013, Interview 16).

Although, as tends to be the case with oral traditions, it is difficult to establish with the accuracy the period to which this description refers, we know from contemporary written accounts that the fortification mentioned was abandoned before the nineteenth century, which means that the pattern described would pre-date Kaabu's decline.

\section{The 2013 fieldwork season: survey}

During five weeks in January and February 2013 I conducted a surface survey covering an area of approximately $70 \times 50 \mathrm{~km}$, from $13^{\circ} 09^{\prime}$ to $12^{\circ} 41^{\prime} \mathrm{N}$ and from $14^{\circ} 36^{\prime}$ to $14^{\circ} 02^{\prime} \mathrm{W}$ (Figure 3 ). Given the combination of poor site visibility, lack of prior information and initial local mistrust of researchers, village-led survey (i.e. survey based on local knowledge) was deemed the most timeeffective method of exploring the region. As efficient and culturally sensitive as this method was, however, it provided no way of assessing the representativeness of the recorded sample. To correct this deficiency, I had initially planned a final week of systematic transect control survey, but this had to be abandoned in light of two factors - the very reduced site visibility (no visible stratification and a lack of surface pottery in non-cultivated areas) and the dense vegetation cover - that rendered it unviable. While the absence of a control mechanism does not invalidate the survey's results, it does limit the sort of conclusions that can be reliably derived from them and is therefore something that will be taken into account in my analysis.

The survey identified and recorded a total of sixty sites, divided into four main types: abandoned villages or tumbu, fortifications or tata, stone marks and guide or subterranean structures. While all of these sites revealed interesting information about the region's history, in this discussion I focus on the 34 identified tumbu as they provide the most information about mobility patterns. Their most prominent trait was the lack of elevation: all the sites encountered, including those corresponding to historical towns mentioned by European accounts and oral traditions, were flat or with very little elevation. Additionally, and notwithstanding the limitations of the survey, it is possible to conclude with confidence that there are no tell-sites in the region. Firstly, because the region covered is a very flat area, where tell-sites would clearly stand out and be difficult to miss. 
Secondly, because we visited all the towns described as permanent power centres by both written and oral historical accounts and in all cases they were flat. Finally, this is a densely populated human landscape, where people live off the land and have an extremely good knowledge of their surroundings. The extent and detail of this knowledge is such that, on several occasions, elders pointed us in the direction of remains of fortifications under $30 \mathrm{~cm}$ high up to $40 \mathrm{~km}$ away. Thus, while it is possible that reliance on local knowledge might have caused us to miss certain types of sites, it is extremely unlikely that it would have been something as prominent and visible as a tellsite.

A second key piece of information from the survey is that most sites abandoned within living memory had associated oral traditions directly connecting their remains with both shifts and relocations, thus strengthening the connection between the pattern and its material correlation. Additionally, the sites that oral traditions consider to be the oldest were also consistently the largest, thus indicating a degree of correlation between size and antiquity, which would be consistent with site shifting patterns (Figure 4). Unfortunately, the extent to which such a correlation could be tested was restricted by the lack of reliable total sizes for most sites (as size was calculated on the basis of surface pottery, which was only visible in cultivated areas).

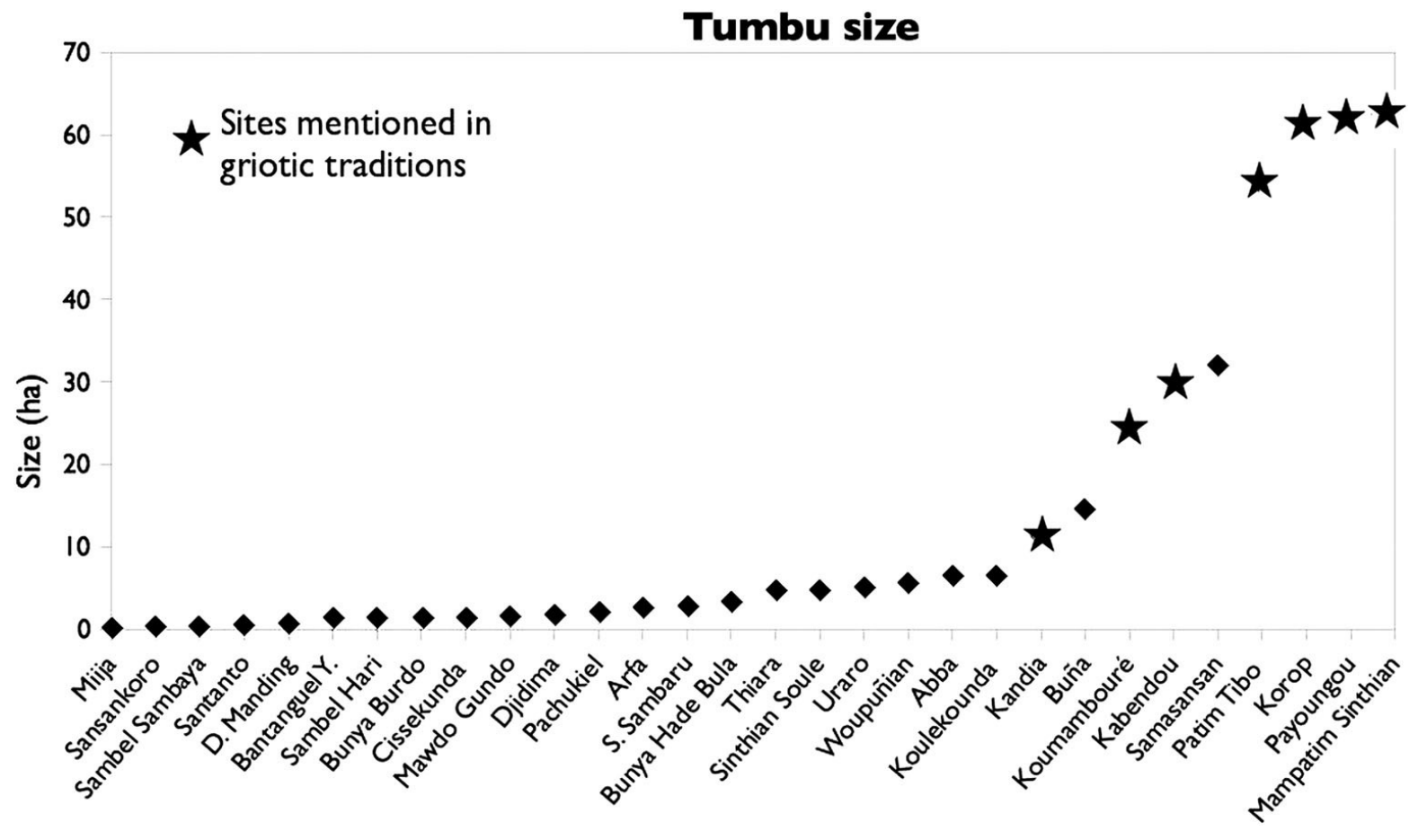

Figure 4. Survey sites: variation in size. 


\section{Excavations: Payoungou}

Following the survey, two sites at opposite corners of the survey area, Payoungou and Korop, were chosen for excavation due to their remarkable size, historical importance, surface evidence and associated oral traditions. Payoungou is currently a village of 1300

inhabitants, $4 \mathrm{~km}$ from the Guinea-Bissau border, which both epics and oral traditions claim was one of Kaabu's original capitals (Giesing and Vidrine 2007: 380). Later, with the move of Kaabu's capital to Kansala (date unknown, but before the eighteenth century), Payoungou was downgraded to the status of a provincial capital but retained its spiritual and symbolic importance as a former power centre. Thus, up until Kaabu's demise, all the candidates to its kingship had to be approved by Payoungou's sacred shrine before they could sit on the throne (Sidibe 1972).

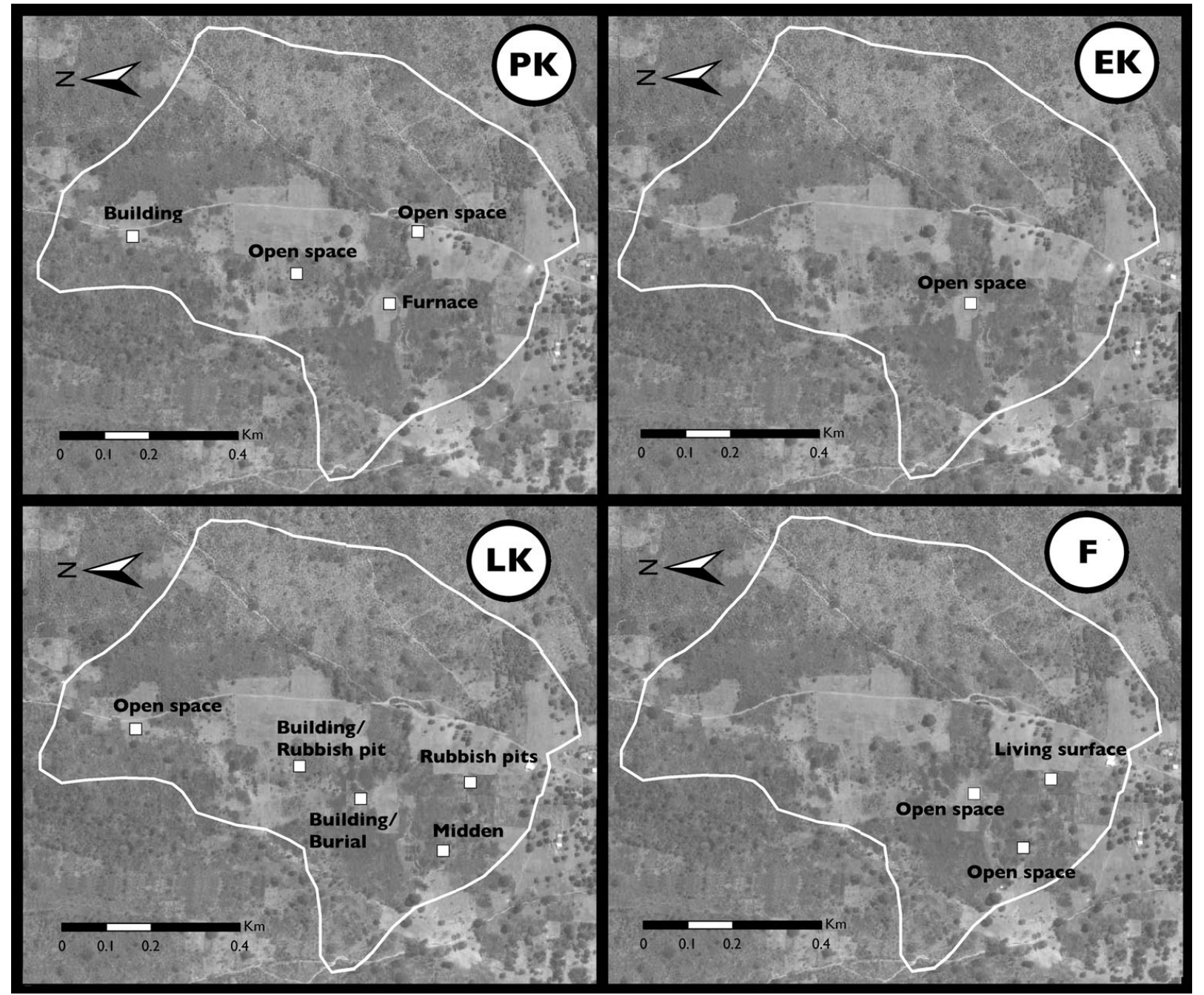

Figure 5. Plan of Payoungou with the seven excavation units (not to scale) showing which were occupied during the pre-Kaabu, Early Kaabu, Late Kaabu and Fulaadu periods. Basemap: (C)2016 Google, (C2016 Digital Globe. 
The archaeological site covers over 66 ha, is located to the north of the current village and, according to local traditions, consists of three main parts: the royal area, the town and Solindioye, an empty buffer zone between the former two, where traitors and horses were buried. Excavations exposed a total area of $46 \mathrm{~m}^{2}$, divided into seven units, ranging from $2 \times 3$ to $2 \times 4 \mathrm{~m}$. Two units were located in the royal area (PYG-B and PYG-F) and another two in Solindioye (PYG-A and PYG-G), with the remaining three distributed across the rest of the site (Figure 5). Overall, these seven units document an occupation spanning 1400 years from the seventh century AD to the present. This dating is based on a combination of radiocarbon dates (Table 1), the ceramic chronology developed as part of this project and chronologically diagnostic small finds (Table 2).

\begin{tabular}{|l|l|l|}
\hline Period & Dates & Defining traits \\
\hline Fulaadu & 19th C & $\begin{array}{l}\text { Presence of 19th C beads and European ceramics } \\
\text { Presence of gin bottle fragments } \\
\text { Presence of smoking pipes } \\
\text { Presence of flint lock gun parts } \\
\text { Pottery: incised and punctate decors }\end{array}$ \\
\hline Late Kaabu & 16th-18th C & $\begin{array}{l}\text { Presence of smoking pipes } \\
\text { Abundance of Galet Rouge beads } \\
\text { Presence of flint lock gun parts } \\
\text { Pottery: incised and punctate decors } \\
\text { Relevant C14 dates }\end{array}$ \\
\hline Early Kaabu & 13th-15th C & $\begin{array}{l}\text { Absence of smoking pipes } \\
\text { Absence of post 15th C imports } \\
\text { Absence of flint lock gun parts } \\
\text { Relevant C14 dates }\end{array}$ \\
\hline Pre-Kaabu & pre-13th C & $\begin{array}{l}\text { Absence of smoking pipes } \\
\text { Absence of post 15th C imports } \\
\text { Absence of flint lock gun parts } \\
\text { Pottery: Orange Gritty Ware } \\
\text { Relevant C14 dates }\end{array}$ \\
\hline
\end{tabular}


While at this stage it is not possible to establish if the occupation of the site was continuous, we do know that Payoungou was not abandoned for any substantial period of time. The oldest horizons (seventh to thirteenth centuries), which were found in PYG-A, PYG-C and PYG-D, demonstrate that Payoungou's foundation predates the Manding arrival and the annexation of the region to the Mali Empire. In addition to the pre- Kaabu deposits, we encountered limited evidence of early Kaabu (thirteenth to fifteenth centuries) in PYG-A and abundant remains of Late Kaabu (sixteenth to eighteenth centuries) and Fulaadu (nineteenth century) horizons. In most cases these deposits were associated with living areas, generally characterised by the presence of coursed earth walls and/or rubbish pits, but they also included a pre-Kaabu iron furnace and a Late Kaabu burial.

Common to all these periods, from pre-Kaabu to Fulaadu, was the shallowness of their deposits and the short-lived nature of individual occupations; despite the antiquity of the site as a whole, all deposits were always under a metre in depth, with the exception of two rubbish pits in PYG-E and PYG-F. Additionally, although the currently available chronological resolution is limited, it is clear that no occupational horizon (with the possible exception of PYG-A's pre-Kaabu iron-producing area) was occupied for longer than 200 years and that most of them were occupied for significantly shorter periods.

\section{Excavations: Korop}

Located in the northwestern corner of the research area, $20 \mathrm{~km}$ south of the Gambian border, Korop is currently a village of approximately 300 inhabitants. Like Payoungou, it features prominently in both local oral traditions and epics, but unlike the former this is not because of its importance during Kaabu, but for its role as a Fulaadu capital. Nevertheless, its inhabitants argue that Korop existed long before the Manding arrival and that it has been an important political centre during all periods. It is undoubtedly one of the largest sites encountered during the survey (>60.6 ha) and the only one with three visible fortifications. 
Table 2. C14 dates from Payoungou and Korop

\begin{tabular}{|c|c|c|c|c|}
\hline Site/Unit/Context & C14 date & Lab number & 1 Sigma Cal. & Material \\
\hline PYG-A 16 & $1390 \pm 30 \mathrm{bp}$ & Beta-348214 & AD 620-650 & Wood charcoal \\
\hline PYG- A 9 & $920 \pm 30 \mathrm{bp}$ & Beta-350837 & AD 1040-1160 & Wood charcoal \\
\hline PYG-B 10 & $250 \pm 30 \mathrm{bp}$ & Beta-349385 & AD 1640-1660 & Wood charcoal \\
\hline PYG-C 3 & $100 \pm 30 \mathrm{bp}$ & Beta-374191 & $\begin{array}{l}\text { AD 1690-1730 } \\
\text { AD1810-1920 } \\
\text { PostAD } 1950\end{array}$ & Wood charcoal \\
\hline PYG-C 15 & $1280 \pm 30 \mathrm{bp}$ & Beta-374192 & $\begin{array}{l}\text { AD } 675-780 \\
\text { AD } 790-870\end{array}$ & Wood charcoal \\
\hline KRP-A 11 & $80 \pm 30 \mathrm{bp}$ & Beta-374188 & $\begin{array}{l}\text { AD 1685-1730 } \\
\text { AD 1810-1925 } \\
\text { Post AD } 1950\end{array}$ & Wood charcoal \\
\hline KRP-C 4 & $120 \pm 30 \mathrm{bp}$ & Beta-374189 & $\begin{array}{l}\text { AD 1665-1780 } \\
\text { AD 1795-1895 } \\
\text { AD 1905-1950 }\end{array}$ & Wood charcoal \\
\hline KRP-D 4 & $740 \pm 30 \mathrm{bp}$ & Beta-374190 & $\begin{array}{l}\text { AD 1255-1290 } \\
\text { AD 1265-1285 }\end{array}$ & Wood charcoal \\
\hline
\end{tabular}




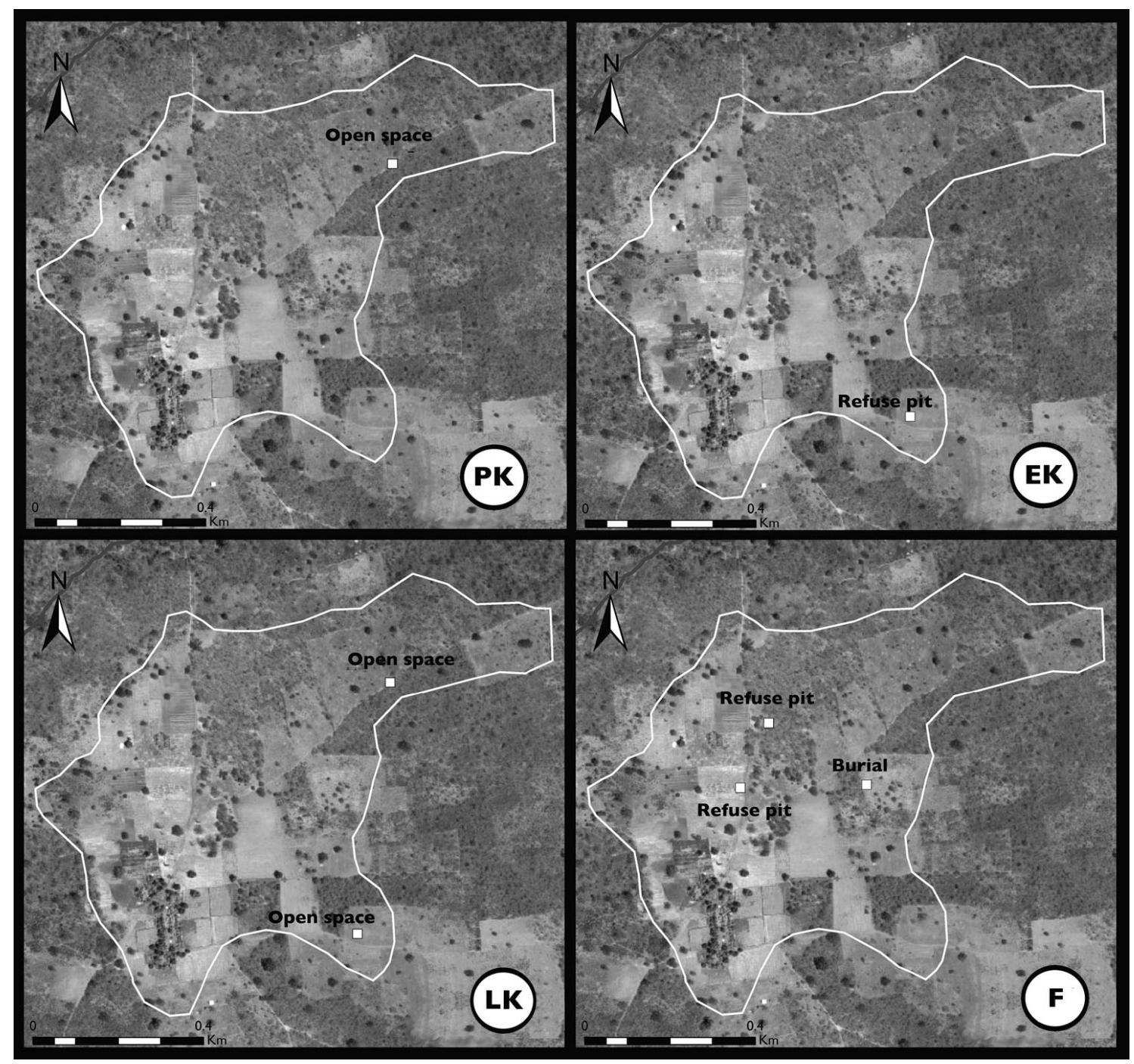

Figure 6. Plan of Korop with the five excavation units (not to scale) showing which were occupied during the pre-Kaabu, Early Kaabu, Late Kaabu and Fulaadu periods. Basemap: (C2016 Google, C2016 Digital Globe, (C2016 AND.

During the two seasons of fieldwork undertaken at Korop a total of $44 \mathrm{~m}^{2}$ was excavated, divided into five units ranging from $2 \times 3 \mathrm{~m}$ to $4 \times 6 \mathrm{~m}$ (Figure 6). As in Payoungou, these uncovered some pre-Kaabu (KRP-C and KRP-E) and Early Kaabu (KRP-E) deposits, as well as many Late Kaabu and Fulaadu horizons. The deposits included several living areas with coursed earth walls, rubbish pits, and a pre-Islamic burial, which together confirm that Korop has been occupied since at least the thirteenth century, but potentially earlier (as we have no absolute dates for the earliest deposits). As was the case in Payoungou, despite the settlement's overall longevity, all the excavated units had less than $1 \mathrm{~m}$ of deposits (with the exception of the rubbish pits in KRP-A and KRP-D) and no single horizon had been occupied for more than 200 years. Additionally, the similarities in the features encountered, the ceramic chronology and the nature of the small finds indicate that Korop and Payoungou have been part of the same technical/cultural sphere since their foundation and 
throughout their history.

\section{Discussion: archaeological evidence of shifting sedentism}

The combination of survey and excavations has provided rich insights into the historical settlement patterns of the Upper Casamance region and the role of mobility in them. Despite its limitations, the surface survey revealed a complete absence of tell-sites in the region, provided direct links between flat sites and oral traditions of shifts, abandonments and foundations and demonstrated a clear correlation between site size and antiquity according to oral traditions. Excavations in Payoungou and Korop confirmed that stratigraphies are indeed very shallow, only surpassing $1 \mathrm{~m}$ in depth in rubbish pits. The chronological resolution currently available is limited, but it is clear that, except for the iron production horizon in PYG-A, all horizons were occupied for less than 200 years and there are indications that in most cases occupation may have been for substantially shorter periods. For instance, in PYG-G in less than 200 years a building was constructed, lived in, abandoned and subsequently used as a burial area. Likewise, occupations in KRP- A, KRP-B and KRP-C were all under 100 years in duration. Therefore, while the currently available chronological resolution is not sufficient to determine how long each horizon was occupied, in most cases this appears to have been a matter of decades, rather than of centuries.

While many units included more than one horizon, in all but two cases only one of them represented a primary occupation (i.e. including structures or other types of features), the rest being sparse scatters of material culture characteristic of peripheral open spaces. The two exceptions to this pattern are PYG-F, where after the closure of the rubbish pits the area became a passage space, as indicated by a compact earthen floor with very small inclusions, and PYG-G, where a burial was dug after the abandonment of the coursed earth structure. The evidence from both sites thus consistently indicates that primary domestic occupations lasted for less than 200 years and that reoccupations appear to have been rare. In other words, both Payoungou and Korop 'shifted' over time.

In order fully to understand the nature of these shifts, it is necessary to assess not just their frequency, but also their direction and range. This is a topic for which archaeology can provide a long-term view not available to any other sources, as oral traditions rarely remember more than two shifts (the most we recorded was three) and written texts tend to provide only a snapshot of particular arrangements at a given time. Unfortunately, it is also a complex issue the full elucidation of which will require far more evidence than that retrieved by this project, although some indications are already available. Figures 5 and 6 summarise the archaeological evidence for each

period in Payoungou and Korop. Two elements are apparent from these maps. First, the pattern of shifts is not regular or linear - in Payoungou the settlement appears to contract and expand from a permanent core in the southern part of the site, while in Korop the scarcity of evidence for 
the earliest periods makes it difficult to discern any patterns. Second, in both sites the current village is immediately south of the Fulaadu occupation, suggesting that at least for the most recent period the shifts were to adjacent areas, rather than to new parts of the site.

Finally, did all areas of the town shift and, if so, did they all shift at the same rate? Local elder traditions, as discussed earlier on, claim that the tata did not shift, that it was fixed and that the village 'orbited' around it (UC 2013, Interview 16). Excavations have revealed that was not the case and that the tata (as exemplified by units PYG-B, PYG-F and KRP-A) did in fact move, but it is perfectly possible that it might have moved at a slower rate. Distinguishing between such rates, is however, beyond the possibilities of the currently available data.

\section{Conclusions}

The review of settlement patterns in the present and recent past of the Upper Casamance region has shown how in its most recent form (from the nineteenth century to the present) shifting sedentism results from the combination of two types of movements: shifts (of whole settlements or of groups within them) and relocations (family groups arriving from or departing for other villages). The overall shifting is therefore the product of the organic sum of a diversity of moves by different population segments, rather than of an intentional global arrangement. This combination of movements produces two parallel phenomena: a permanent landscape of stable yet shifting historical towns and an ephemeral one characterised by the continuous creation and abandonment of minor villages. The reasons behind all of these moves are as diverse as the moves themselves, ranging from environmental to social concerns, but they all have in common the use of mobility (whether short- or long-distance) as a problem-solving mechanism, while maintaining a fully sedentary lifestyle and a strong sense of the importance of historical towns as permanent anchors in the landscape.

Archaeologically, the results from both survey and excavation indicate that shifting pat- terns are not a recent occurrence. Both Payoungou and Korop have been inhabited for over 1300 and 800 years, respectively, yet no single part of either site was inhabited for more than 200 years. As for the nature of the shifts, it is clear that they were not linear (which is consistent with shifting patterns as currently known) and that re-occupations of previously abandoned areas were rare. The fact that no tell-sites exist in the region, even in documented historical settlements, would indicate that this pattern extended throughout the Upper Casamance. In short, we can now assert that shifting patterns have been a defining trait of the Upper Casamance since at least the time of Kaabu perhaps earlier.

This has implications for our understanding of the Upper Casamance's history, but also for wider

archaeological discussions. Firstly, this is because Kaabu and Fulaadu, the two states that have 
defined the political landscapes of the Upper Casamance for the last 800 years, fit the traditional definition of 'state' at many levels: they were based around territories and strongholds with a defined regional hierarchy, had a centralised system of tax col- lection and a ruling aristocracy that controlled access to prestige goods in general and imports in particular. Yet, as the previous discussion shows, both states were based on political landscapes with continuously shifting political centres and moving populations, at odds with traditional conceptualisations of states as static territorial entities.

A second implication follows from the fact that archaeological studies of mobility have tended in the past to rely on binary sedentary/nomad divisions and on frameworks that present movement as a transitional response to moments of crisis (e.g. Higgs and Vita- Finzi 1972; Rafferty 1985; Binford 1990). In the case of the Upper Casamance, however, movement is not a temporary phase between still moments, but an intrinsic and constant dimension of the articulation of social dynamics. Furthermore, this constant movement takes place in populations with fully sedentary lifestyles, which also defies many traditional assumptions about mobility. The case of the Upper Casamance is not unique, as examples of shifting settlements have been documented elsewhere (see discussion above), but these cases remain generally under-theorised, rarely make it into discussions about mobility, and, when they do, it tends to be with great doses of environmental determinism.

Finally, the discussion about shifting sedentism also has important methodological implications as shifting towns may be easily misidentified as ephemeral settlements, if no historical evidence for the length of the occupation exists or if no dated ceramic sequences (indicating a possible multiperiod occupation) are available. It is therefore very likely - given the traditional focus of West Africanist archaeologists on tell sites - that shifting settlements may have often been misidentified as transient sites and over- looked, leading to an under-representation of shifting sedentism in the literature.

\section{Note}

1. The term 'children' may not necessarily refer only to them since it is also often applied to young people and/or to soldiers.

\section{Acknowledgements}

I should like to thank Prof. Kevin MacDonald and Prof. Andrew Reynolds for their guidance and support throughout this project and Prof. Ibrahima Thiaw and Prof. Hamady Bocoum for their advice and assistance in Senegal. I am also grateful to the elders of Mampatim Maoundé, Payoungou, Korop and the rest of the villages visited, without whom this project would not have been poss- ible. This work was funded by the Arts and Humanities Research Council, the British 
Federation for Women Graduates, the Worshipful Company of Art Scholars, the Institute of Archaeology of University College London (UCL), the UCL Graduate School and the University of Edinburgh.

\section{References}

Alvares de Almada, A. 1964 [1594]. Tratado Breve dos Rios de Guiné do Cabo Verde. Lisbon: LIAM.

ANSD 2009. Situation Economique et Sociale de la Région de Kolda. Service Régional de la Prévision et de la Statistique. Dakar: Ministère de l'Économie et des Finances.

Barnard, H. and Wendrich, W. 2008. The Archaeology of Mobility. Los Angeles: University of California Press.

Bertrand-Bocande, E. 1849. "Notes sur la Guinée portugaise ou Sénégambie méridionale.” Bulletin de la Société de Géographie 12: 57-93.

Binford, L.R. 1990. "Mobility, housing, and environment: a comparative study." Fournal of Anthropological Research 46: 9-52.

Boutillier, J.-L. 2011. Extrait du Rapport de Monsieur Fean-Louis Boutillier. Dakar: Université Cheick Anta Diop.

Braudel. F. 1981. The Structures of Everyday Life: The Limits of the Possible. London: Harper \& Row.

Craig, N.M. and Chagnon, N. 2006. "Locational analysis of Yanomamo gardens and villages observed in satellite imagery." In Archaeology and Ethnoarchaeology of Mobility, edited by F. Sellet, R. Greaves and P.-L. Yu, 44-74. Gainesville: University Press of Florida.

Fanchette, S. 1999. "Migrations, intégration spatiale et formation d'une société peule dans le Fouladou (haute Casamance, Sénégal)." In Figures Peules, edited by R. Botte, J.Boutrais and J. Schmitz, 165-192. Paris: Karthala.

Fanchette, S. 2010. Une Région Periphérique à l'Epreuve de la Décentralisation: Le Fuladu, Pays des Peul de Haute-Casamance (Sénégal). http://www.enda-sigie.org/bases/sigie/ressources/edocs-fan-decentfuladu-hte-casam.pdf

Giesing, G. and Vidrine, V. 2007. Tarikh Mandinka de Bïini (Guinée-Bissau): La Mémoire des Mandinka et Sooninkee du Kaabú. Leiden: Brill.

Hecquard, H. 1853. Voyage sur la Cote et l'Intérieur de l'Afrique Occidentale. Paris: Bernard et Co. 
Higgs, E.S. and Vita-Finzi, C. 1972. "Prehistoric economies: a territorial approach." In Papers in Economic Prehistory, edited by E.S. Higgs, 27-36. Cambridge: Cambridge University Press.

Jackson, J.B. 1984. Discovering the Vernacular Landscape. New Haven: Yale University Press.

Jones, E.E. and Wood, J.W. 2012. "Using event-history analysis to examine the causes of semisedentism among shifting cultivators: a case study of the Haudenosaunee, AD 1500-1700." Fournal of Archaeological Science 39: 2593-2603.

Kelly, R.L. 1992. "Mobility/sedentism: concepts, archaeological measures, and effects." Annual Review of Anthropology 21: 43-66.

Kohler, T.A. and M.H. Matthews 1988. "Long-term Anasazi land use and forest reduction: a case study from southwest Colorado." American Antiquity 53: 537-564.

Labat, J.B. 1728. Nouvelle Rélation de l’Afrique Occidentale IV. Paris: Guillaume Cavalier.

Lawson, A. 2003. "Megaliths and Mande states: sociopolitical change in The Gambia valley over the past two millennia." PhD diss., University of Michigan.

Lindsay, I. and Greene, A. 2013. "Sovereignty, mobility, and political cartographies in Late Bronze Age southern Caucasia.” Journal of Anthropological Archaeology 32: 691-712.

Murdoch, P. 1967. "The Ethnographic Atlas: a summary.” Ethnology 6: 109-236.

Péllissier, P. 1966. Les Paysans du Sénégal: Les Civilisations Agraires du Cayor à la Casamance. Sant- Yrieix: Imprimerie Fabrègue.

Rafferty, J.E. 1985. "The archaeological record on sedentariness: recognition, development, and implications." Advances in Archaeological Method and Theory 8: 113-156.

Roche, C. 1985. Histoire de la Casamance: Conquête et Résistance: 1850-1920. Paris: Karthala.

Sidibe, B.K. 1972. "The story of Kaabu: the fall of Kaabu." Proceedings of the Conference on Manding Studies. London: School of Oriental and African Studies.

UC 2013. Upper Casamance Project Archives. Transcripts of taped interviews in Pulaar and Manding, translated into French. 